\title{
The Concept of Decision Support in Evaluating the Functional State of Complex System of the Biological type
}

\author{
Rashit Nasyrov \\ Department of Computer Science and Robotics \\ Ufa State Aviation Technical University \\ Ufa, Russia \\ nrash@yandex.ru \\ Rustem Zulkarneev \\ Department of Inner Deceases \\ Baskir State Medical University \\ Ufa, Russia \\ zurustem@mail.ru
}

\author{
Nafisa Yusupova \\ Department of Computer Science and Robotics \\ Ufa State Aviation Technical University \\ Ufa, Russia \\ yussupova@ugatu.ac.ru \\ Alexandr Kruzhkov \\ Department of Computer Science and Robotics \\ Ufa State Aviation Technical University \\ Ufa, Russia \\ danteform@gmail.com
}

\begin{abstract}
The aim of the work is to develop a conceptual approach to decision support in assessing the functional state of a complex system of biological type. The definition of the functional state and the basic principles of its evaluation for complex systems of biological type on the basis of system representations are formulated. A situational model of the problem environment as a set-theoretic composition of the main components and evaluation functions was developed, which allowed to formulate the definition of the problem situation. The structure of the application of data mining to assess the functional state of a complex system using as feedback models of three levels - strategic, tactical and operational. A system of coordinated models for decisionmaking in assessing the functional state of a complex system based on causal representations in the form of Markov chains and Petri nets is proposed.
\end{abstract}

Keywords-decision support, functional state, complex system

\section{INTRODUCTION}

The term functional state has long been firmly established in the arsenal of biomedical researchers as a basis for assessing, forecasting and making decisions, for example, work [1]. At the same time, the concept of a functional state turned out to be practically useful so that work appeared on the application of this concept and estimation methods in technical systems [2], energy [3], and other fields.

From the point of view of the level of description, most of the works are devoted to assessing the functional state of an organism or a complex system as a whole. With the development of this approach, the use of more complex means and methods was required. This led to the fact that in biomedical research the evaluation of the functional state was divided by the types of manifestations of life: vegetative, somatic and mental [4]. Moreover, a number of studies examine the functional state of individual subsystems and components of complex systems. One of the drawbacks of such works is the ambiguity of the description and interpretation of particular results from the point of view of the original holistic system. As a rule, this is due to the hierarchical feature of complex systems consisting in the fact that decomposition and study of the structural, functional and regulatory functions of subsystems and components quite often do not coincide. For example, when examining the cardiovascular system, only the heart and large vessels are independent organs for research. In this case, small vessels and capillaries included in the so-called. regional blood flow are anatomically constituent components of the organs that they supply blood.

In connection with these, the development of a certain invariant approach to the presentation of the functional state of complex systems of various nature is required to provide decision support for the evaluate and prediction of their functional state.

\section{STATE OF ART}

Evaluation of the quality and efficiency of systems and processes of different nature is quite a challenge. In different subject areas methods and techniques of evaluation have different names and have an excellent structure. However, most of them are devoted to assessing the quality of the object, which can be generalized by the concept of functional state. Due to the variety of methods and approaches to the assessment of the functional state, it is possible to note the weak development of the methodological basis. Thus, it is necessary to develop a common methodological approach to solving the problem of assessing the functional state of a complex object.

In the past few decades, various approaches have been developed to describe and model both individual elements, as well as a holistic view of complex systems of industrial, economic and social nature. These models have evolved as part of organizational, technical, and biotechnical systems concepts. 
The set of works in the first direction is focused on the study of the processes of functioning and management of social, economic and other types of organizations that have, as a rule, a hierarchical structure, due to the purpose of the system, and determining the nature of management, implemented on the basis of subordination in the hierarchy, as reflected in the works $[5,6]$.

Publications in the second direction are devoted, as a rule, to the research, analysis, and design of complex manmachine complexes, for example, production systems, as well as to the solution of problems associated with these types of activities [7-11].

Research in the third area is devoted to individual aspects of human interaction with the technical system. At the same time, a person could act both as an active actor, realizing his goals, and as a passive object, to which the impact is directed. This may include the results of research in the field of ergonomics and engineering physiology, as well as the protection of human life [12].

Note that recently, a number of studies have been devoted to decision support in the biomedical field, for example [13-15].

In world practice, research for solving decision support tasks is presented quite widely. For example, the work [16$20]$ is devoted to multi-agent modelling of processes in healthcare. Work [21] is devoted to a rare topic - decision support in the treatment of osteoporosis. Studies [22-24] describe the tasks of decision support in healthcare informatics. The papers $[25,26]$ describe decision support in antibiotic therapy. Publications [27-30] are devoted to decision-making in sorting patients and providing assistance in emergency situations. The work [31] describes DSS for interpretation of ECG in 12 leads. Articles [32, 33] are devoted to decision making in risk analysis. Publication [34] describes the use of decision trees and support vector machines for diagnosing the causes of cough. The study [35] is dedicated to the personalization of decision support systems. The article [36] presents the results of developing a decision-making system in the treatment of lower back pain. The study [37] is devoted to the application of simulation dynamics of the study of health processes. The work [38] describes the classification of design automation systems in biomedical engineering.

Note that the subject of the work is heterogeneous and does not give a holistic view of decision support systems in biomedical practice. Moreover, publications devoted to the use of DSS for assessing the functional state of complex systems of biological and biotechnological type are poorly presented. For example, only works [21] and [31] can be attributed here. This state of the issue is also unsatisfactory due to modern demands of society, reflected in the tasks of the formation of technologies and systems of personal medicine.

\section{THE PURPOSE AND OBJECTIVES OF THE STUDY}

The aim of the work is to develop a conceptual approach to decision support in assessing the functional state of a complex system of biological type. To do this, you need to solve the following tasks:
- Formulate a definition of a functional state and the basic principles of its assessment.

- To develop a situational model of the problem environment as a basis for constructing decisionmaking models in assessing the functional state.

- Develop a data mining application structure for assessing the functional state of a complex system.

- To propose a system of models for decision making when assessing the functional state of a complex system.

There are many definitions of the functional state of the object of study, for example, given in $[1,2,3,4]$. However, the definitions in the mentioned essentially depend on the nature of the system under study. In this regard, there is a need to formulate a definition adequate to the tasks.

Under the functional state of a complex system, we understand a set of characteristics of functions and properties that determine the level of activity and are necessary for the implementation of behavior programs.

Consider the basic principles of assessing the functional state of a complex system of biological type.

The principle of hierarchy. Evaluation of the functional state of a person and evaluation of the state of his physiological functions require different approaches and are based on different principles, and the retention of physiological (in particular, homeostatic) constants within the so-called "norm" is not the purpose of the existence of the organism, and a means of ensuring the necessary level of metabolism and energy [40].

The principle of homeostasis. Homeostasis - selfregulation, the ability of an open system to maintain the constancy of its internal state through coordinated reactions aimed at maintaining dynamic equilibrium. The desire of the system to reproduce itself, to restore the lost balance, to overcome the resistance of the environment [4].

The principle of coherence of the body. The ability of an organism to maintain itself as an integral system of interacting elements during environmental changes, in particular under loads and extreme conditions [4].

The principle of integration of functions in the body. The integral parameters of the functional state should include not only indicators of a person's health and efficiency of his activity, but also the results of an objective quantitative assessment of physiological processes and, very importantly, the functioning of regulatory systems of the body, ensuring its integrity due to the integration of functions [4].

\section{SitUATIONAL APPROACH TO THE DESCRIPTION OF THE PROBLEM SITUATION OF FUNCTIONAL STATE ASSESSMENT}

Specialist activity takes place in a specific subject area or operating environment. The concept of the operating environment is a basic concept in the construction of a generalized model of the problem situation. The totality of the subject area and technology of the subject, information and cognitive activities of the LPR in this area will be called a problem operating environment in this area. In the analysis of the essential properties of such a medium in the praxeological approach [41] usually distinguish:objects of 
activity;stakeholder;operation tools;information and operational scheme (methods of activity);time reserve.

The methods of action can in general be defined by an algorithm, a rule, a technological description, which is the information part of the method of action. The instrumental part is a set of tools, resources, and the actions themselves that are carried out by the DM and about which he can report, that is, formulate one of three general statements:

- The action $x$ started at time $t_{0}$ under the initial conditions $u\left(t_{0}\right)$.

- Action x develops (continues) in accordance with one of its variants.

- The action $x$ ended at time $t_{0}$ under the conditions $u\left(t_{0}\right)$.

Through the interaction of these components, the entire dynamics of the operating environment is described. Formally, the mathematical operating environment can be defined as the Cartesian product of the sets $\{\mathrm{O}\},\{\mathrm{S}\},\{\mathrm{A}\}$, $\{\mathrm{I}\},\{\mathrm{T}\}$ :

$$
\{\mathrm{OC}\}=\{\mathrm{O}\} *\{\mathrm{~S}\} *\{\mathrm{~A}\} *\{\mathrm{I}\} *\{\mathrm{~T}\}
$$

Where $\{\mathrm{OS}\}$ is the set of operating environments; $\{\mathrm{O}\}$ many objects; $\{\mathrm{S}\}$ - set of subjects $(\mathrm{DM}) ;\{\mathrm{A}\}$ - many tools; $\{\mathrm{I}\}$ - many information and operational schemes (scenarios); $\{\mathrm{T}\}$ - many points in time.

These components can be understood as designations of such entities, which in practice can act as resources. Indeed, in the process of any activity, these elements are included, included, transferred to the final result. For example, in the production process, an object can be partially processed by a subject, acting with a specific tool, according to a given technological instruction at the natural rate of time movement.

Each of the listed components of the components of the operating environment can be characterized by a set of values arising from the use of measuring instruments, devices, standards, models. That is, each resource can be measured by a set of parameters that can take values from any suitable scale.

Thus, the concept of a state space is introduced, which is a Cartesian product of the set of possible values of the parameters of the elements:

$$
\{\text { Sit }\}=\left\{\mathrm{P}_{\mathrm{O}}\right\} *\left\{\mathrm{P}_{\mathrm{S}}\right\}^{*}\left\{\mathrm{P}_{\mathrm{A}}\right\} *\left\{\mathrm{P}_{\mathrm{I}}\right\} *\left\{\mathrm{P}_{\mathrm{T}}\right\}
$$

This makes it possible to determine the basic situation in the operating environment as:

$$
S i t^{\prime}=\left\langle\bar{P}_{O_{j}}^{i}, \bar{P}_{S_{j}}^{i}, \bar{P}_{S_{j}}^{i}, \bar{P}_{I_{j}}^{i}, \bar{P}_{T_{j}}^{i}\right\rangle
$$

where $\mathrm{i}$ - corresponds to the $\mathrm{i}$-th element of the operating environment $\mathrm{OSi}=\langle\mathrm{Oi}, \mathrm{Si}, \mathrm{Ai}, \mathrm{Ii}, \mathrm{Ti}\rangle$; $\mathrm{j}$ - corresponds to the jth set of parameters; $\mathrm{P}$ - parameter vector of OS elements.

In accordance with this axiomatics, a situation can be understood as a subset of the space of elementary situations.
In the class of situations, a special subset can be distinguished - problem situations (PS). In terms of content, they should include such situations that are burdened, from the point of view of the subject, by uncertainty, the threat of loss of resources, the rapid pace of development and the emergence of the functional state of a complex system to a subcritical level.

In order to be able to display these factors, it is necessary to be able to determine the state of resources under conditions of stochasticity or uncertainty of their behavior, if it is possible to measure them, as well as in conditions of uncertainty associated with the impossibility of measuring some characteristics of resources due to the lack of measurement and metrological models. That is, a problem situation can be determined by setting a subset of the space of situations, a function or a measure of the state of resources as a function of their parameters and a dividing (estimated) function of the subject, allowing to take into account the above uncertainties. Thus, the subspace of problem situations equipped with a measure of the state of resources and the evaluation function of the subject:

$$
\{\mathrm{PSit}\}=\left\langle\{\text { Sit }\}, \mathrm{R}\left(\mathrm{P}_{\mathrm{O}}, \mathrm{P}_{\mathrm{S}}, \mathrm{P}_{\mathrm{A}}, \mathrm{P}_{\mathrm{I}}, \mathrm{P}_{\mathrm{T}}\right), \operatorname{Pr}(\mathrm{R},\{\mathrm{Sit}\})\right\rangle,
$$

where $\{$ Sit $\}$ is a subset of situations; $\mathrm{R}$ (.) - function or measure of the state of resources; $\operatorname{Pr}($.$) - the evaluation function of the subject or the rule of$ referring to one of the classes of PS.

In the general case, the evaluation function can be interpreted as an assessment of the functional state.

The main feature of PS as an object is that it cannot be described in the framework of one model. In addition, an additional property of PS is its reflexivity, that is, the ability of individual elements (DM) reflects the entire object in its models, representations, descriptions.

\section{USING DATA MINING WITH FEEDBACK TO ASSESS THE FUNCTIONAL STATE OF COMPLEX SYSTEMS}

Implementation of the considered situational approach taking into account the above principles is possible within the technology of decision support systems. An invariant approach is to use the structure of hybrid-type DSS presented in $[10,37,50]$. However, within the framework of the adopted structure, it is necessary to determine the way of interaction of three types of databases - databases, models and knowledge. The need to use these three types of databases is due to the current level of technology development in the field of data analysis and decisionmaking methods.

In accordance with this, as a basis for the application of models and methods of decision-making is an array of initial practical or experimental data accumulated during the operation of the system. Quite often, the amount of such data is large and very large. In this regard, the approach used implicitly falls into the mainstream of the research direction, generally called data mining [43]. At the same time, in the process of functioning of the DSS on the basis of the models used, an array of data is studied in accordance with the methods of data mining. The found regularities as they are identified constitute the knowledge base of the subject area, thereby increasing the amount of knowledge of the DSS. The 
obtained empirical regularities are generally of mass character and under certain conditions can be formalized to the level of models with subsequent inclusion in the base of models. The resulting models can be used as a paradigm for the main stages of the data mining. In this case, they act as feedback that improves the quality of the implementation of the data mining (figure 1).

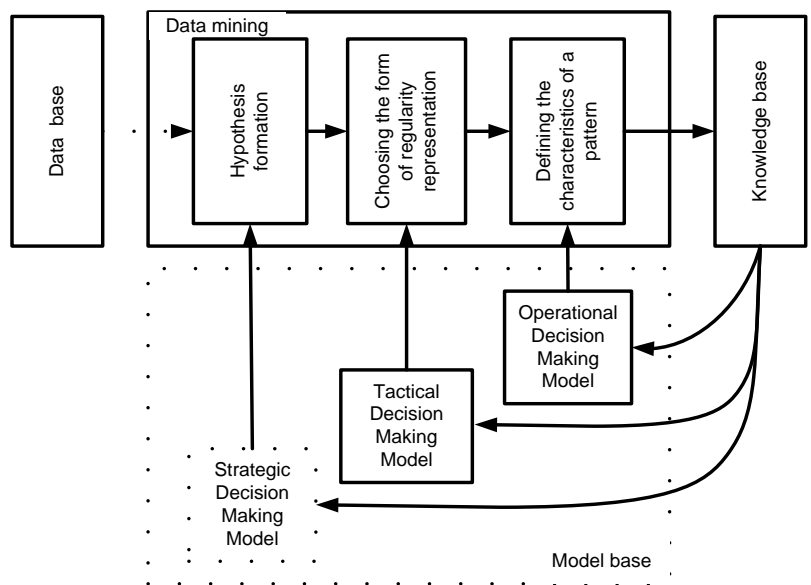

Fig. 1. Structure of the data mining system with feedback

\section{SYSTEM OF COORDINATED MODELS FOR DECISION- MAKING ON FUNCTIONAL STATE ASSESSMENT}

When considering the decision-making process for assessing the functional state, three levels of models can be identified. The most General level is strategic (forecasting and planning), further - tactical (organization of activities) and operational (implementation of actions) [10,11]. One of the most effective models of construction, transformation and determination of the resulting performance indicators are models based on causal representations [11].

It is assumed that at the level of forecasting and planning, the characteristics and parameters linking the target settings with the properties and limitations of the problem environment are determined, the position of the system on the life cycle trajectory is determined. Considering biomedical systems as an example, it is appropriate to use models of the type of social dynamics characterizing the conditional transition from one stage of the disease to another or to the restoration of health. If we consider chronic diseases with States of exacerbation and remission, here as a model we can use the graph presented in Fig.2. Loading transitions probabilities or intensities can investigate the behavior of the corresponding population of patients.

Tactical level models characterize sets of actions to minimize deviations from decisions. At this level, it is necessary to build a sequence of sets of actions found at the organizational level from the conditions of feasibility and effectiveness of achieving the goal. Thus, it is proposed to define such sequences of actions with multi-criteria assessments of the effectiveness and risk of achieving the goal as information-operational schemes [10], an example of which is presented in figure 3 .

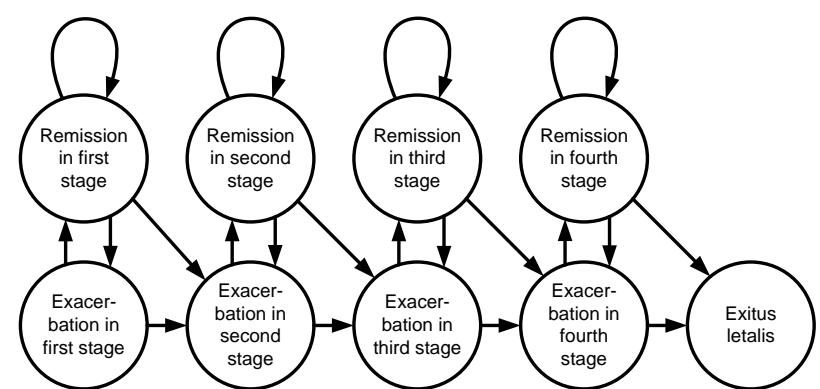

Fig. 2. The dynamics of developing a chronic disease

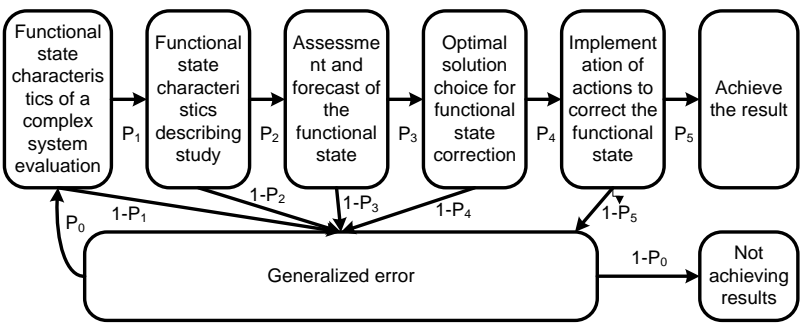

Fig. 3. Information-operational decision-making scheme in assessing the functional state

In fact, the graph is a detailed description of actions aimed at ensuring the transition from the stage of exacerbation to the stage of remission in the graph of figure 2 . In this case, the achievement of the result corresponds to the transition to a state of remission, and the failure to achieve the result of any other adverse outcome.

The sequence of action at the operational level can be partially or fully automated [51], which allows to depict it in one of the forms of representation of finite state machines, for example, in the form of a Petri network-fig 4.

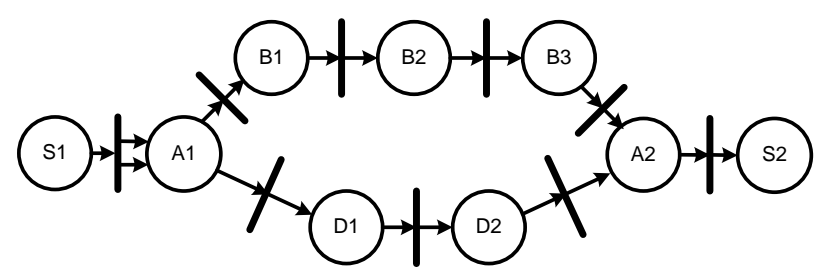

Fig. 4. General algorithm of research in the form of medical and biological experiment

This view allows you to conduct automated research in various ways, including remotely.

\section{CONCLUSION}

As a result of the research, a conceptual approach to decision support in assessing the functional state of a complex system has been developed.

To formulate the definition of the functional state and the basic principles of its evaluation for complex systems of biological type on the basis of system representations.

A situational model of the problem environment as a settheoretic composition of the main components and evaluation functions was developed, which allowed to formulate the definition of the problem situation. 
Anew structure of the application of data mining to assess the functional state of a complex system using as feedback models of three levels - strategic, tactical and operational.

A new system of coordinated models for decisionmaking in assessing the functional state of a complex system based on causal representations in the form of Markov chains and Petri nets is proposed.

\section{ACKNOWLEDGMENT}

The reported study was funded by RFBR according to the research projects№ 17-48-020074,№ 19-07-00780.

\section{REFERENCES}

[1] Baevskij P.M. Prognozirovanie sostoyanij na grani normy i patologii. - M.: Medicina. - 1979. - 295s. (Bayevsky P. M. Prediction of States on the verge of norm and pathology. — M.: Medicine. — 1979. 295 p.)

[2] Kirillov N.P. Konceptual'naya model' ob"ekta situacionnogo upravleniya funkcional'nymi sostoyaniyami tekhnicheskih sistem// Iskusstvennyj intellect $i$ prinyatie reshenij, 2012, №4, S.61-75. (Kirillov N. P. Conceptual model of the object of situational management of functional states of technical systems// Artificial intelligence and decision-making, 2012, №4, Pp. 61-75.)

[3] Moshinskij O.B. Razrabotka modeli ocenki funkcional'nogo sostoyaniya sistemy elektrosnabzheniya megapolisov. Avtoref.diss. na soisk. uch. st.kandidata tekhnicheskih nauk., Ekterinburg, 2011.24 s. (Moshinsky O. B. Development of a model for assessing the functional state of the power supply system of megacities. Abstract on competition of a scientific degree. academic article of candidate of technical Sciences., Ekaterinburg, 2011.-24 PP.)

[4] Samojlov V.O. Metodologiya i metody ocenki funkcional'nogo sostoyaniya cheloveka// Biotekhnosfera, 2009, №6.-S.14-16. (Samoilov V. O. Methodology and methods of evaluation of the functional state of man//Biotechnosphere, 2009, №6.-Pp. 14-16.)

[5] N. I. YUsupova, G. R. SHahmametova, Podderzhka prinyatiya reshenij pri antikrizisnom upravlenii na osnove intellektual'nyh tekhnologij: monografiya. - Moskva : Mashinostroenie ; Ufa : Ufimskij gos. aviacionnyj tekhnicheskij un-t, 2012. - 244 s. (Support decision-making in crisis management based on intelligent technologies: monograph / N. I. Yusupova, G. R. Shakhmametova. Moscow : mechanical engineering ; Ufa : Ufa state aviation technical University, 2012. - 244 p.)

[6] Volkov S.D., Galuzina S.M., Upravlencheskoe reshenie v organizacionnoj sisteme upravleniya. In: Nauchnyj zhurnal NIU ITMO. Seriya «Ekonomika $i$ ekonomicheskijmenedzhment», 2016, №2.-S.92-99. (Management decision in organizational management system/ Volkov S. D., Galuzina S. M. / Scientific journal of ITMO. Series "Economics and economic management", 2016, №2.-P. 9299.)

[7] R.A.Badamshin, B.G.Il'yasov, L.R.Chernyahovskaya , Problemy upravleniya slozhnymi dinamicheskimi ob"ektami v kriticheskih situaciyah na osnove znanij. M.: Mashinostroenie, 2003 - 240 s. (Problems of control of complex dynamic objects in critical situations on the basis of knowledge / R. A. badamshin, B. G. Ilyasov, L. R. Chernyakhovskaya. M.: mechanical engineering, 2003 - 240 p.)

[8] YUsupova N.I., SHahmametova G.R., Enikeeva K.R. Modeli predstavleniya znanij dlya identifikacii opasnostej promyshlennogo ob"ekta// Vestnik UGATU, Seriya "Upravlenie, vychislitel'naya tekhnika i informatika», Ufa, 2008. - S.91-100. (Yusupova N. I., Shakhmametova G. R., Enikeeva K. R. Models of knowledge representation for identification of industrial facility hazards// Bulletin of USATU, Series "Management, computer engineering and Informatics", Ufa, 2008 - Pp. 91-100.)

[9] Rizvanov D.A., YUsupova N.I., Osnovy podderzhki prinyatiya reshenij pri upravlenii resursami v slozhnyh sistemah s primeneniem intellektual'nyh tekhnologij. Sovremennye naukoemkie tekhnologii, 2017, №1.-S.69-73. (Fundamentals of decision support in resource management in complex systems using intelligent technologies/ Rizvanov D. A., Yusupova N. I. /Modern science-intensive technologies, 2017, №1.-P. 69-73.)
[10] Nasyrov R.V. Avtomatizirovannaya sistema prinyatiya reshenij na osnove prichinnyh modelej $\mathrm{v}$ problemnyh situaciyah.-Avtoref. diss. na soisk. step. kand.tekh. nauk.-Ufa:UGATU,1994. (in Russian)

[11] Bakusov L.M., Nasyrov R.V., Lebedev E.G. Prichinnyj analiz dlya prinyatiya reshenij./Uchebnoe posobie.-Ufa:UGATU,1993.-96s. (Bakusov L. M., Nasyrov R. V., Lebedev E. G. Causal analysis for decision-making./Textbook.-Ufa:USATU,1993.-96c.)

[12] Ahutin V.M, Inzhenernaya fiziologiya i modelirovanie sistem organizma.-Novosibirsk: Nauka, 1987.-150s. (Engineering physiology and modeling systems of the body./ Akhutin V. M. et al.Novosibirsk: Nauka, 1987.-150s.)

[13] Khalafyan A.A. Analiz i sintez medicinskih sistem podderzhki prinyatiya reshenij na osnove tekhnologij statisticheskogo modelirovaniya Special'nost' 05.13.01 - Sistemnyj analiz, upravlenie i obrabotka informacii (informacionnye i tekhnicheskie sistemy) Avtoref. diss. na soisk. uchenoj step. D-ra tekh. nauk. Krasnodar 2010. (Khalafyan A. A. Analysis and synthesis of medical decision support systems based on statistical modeling technologies Specialty 05.13.01 - System analysis, management and processing of information (information and technical systems) THESIS abstract for the degree of doctor of technical Sciences. Krasnodar - 2010.)

[14] Koshkarov A.A. Podderzhka prinyatiya reshenij dlya zadach medikoekonomicheskogo kontrolya naznacheniya lekarstvennyh sredstv/ Fundamental'nye issledovaniva - 2016. - № 4 (chast' 1) - S. 71-75. (Kashkarov A. A. decision Support for the problems of medical and economic control of prescription of medicines/ Basic research. 2016. - № 4 (part 1) - Pp. 71-75.)

[15] Litvin A.A., Litvin V.A. Sistemy podderzhki prinyatiya reshenij v hirurgii/ Novosti hirurgii tom 20, nomer 1, 2012 god, S. 96-100. (Litvin A. A., Litvin V. A. Decision support systems in surgery/ surgery news volume 20 , number 1,2012 , Pp. 96-100.)

[16] Nesrine Zoghlami, Besma Glaa, Souad Rabah, Mourad Abed Healthcare decision support tool: multi-agent system for bed management // Int. J. Applied Management Science, Vol. 10, No. 1, 2018.

[17] Elhadi Shakshuki, Malcolm Reid Multi-Agent System Applications in Healthcare: Current Technology and Future Roadmap // The 6th International Conference on Ambient Systems, Networks and Technologies (ANT 2015). Procedia Computer Science 52 ( 2015 ), pp $252-261$

[18] Raman Paranjape and Asha Sadanand, Multi-agent Systems for Healthcare Simulation and Modelling, New York, 2010.

[19] Colja A. Becker, Fabian Lorig, and Ingo J. Timm Survey of Multiagent Systems for Improving Home Health Care Management. AIH@ IJCAI, 2018.

[20] Saito, K.; Asada, T.; Yoshitomi, Y.; Kato, R.; Tabuse, M. A Recipe Decision Support System Using Knowledge Information and Agent// Journal of robotics networking and artificial life, Vol.5, Issue 3, 2019, PP.204-207, DOI: 10.2991/jrnal.2018.5.3.13

[21] Gudmundsson, H.T.; Hansen, K.E.; Halldorsson, B.V.; Ludviksson, B.R.; Gudbjornsson, B.Clinical decision support system for the management of osteoporosis compared to NOGG guidelines and an osteology specialist: a validation pilot study// Bmc medical informatics and decision making, Vol.19,№27, DOI: 10.1186/s12911019-0749-4.

[22] Alkahtani, M.; Choudhary, A.; De, A.; Harding, J.A. A decision support system based on ontology and data mining to improve design using warranty data/ Computers \& industrial engineering, Vol.128, pp. 1027-1039, DOI: 10.1016/j.cie.2018.04.033.

[23] Garcia-Alonso, C.R.; Almeda, N.; Salinas-Perez, J.A.; GutierrezColosia, M.R.; Uriarte-Uriarte, J.J.; Salvador-Carulla, L. A decision support system for assessing management interventions in a mental health ecosystem: The case of Bizkaia (Basque Country, Spain)// PLOS ONE, Vol.14, Issue 2, 2019, e0212179, DOI: 10.1371/journal.pone.0212179.

[24] Jayaratne, M.; Nallaperuma, D.; De Silva, D.; Alahakoon, D.; Devitt, B.; Webster, K.E.; Chilamkurti, N. A data integration platform for patient-centered e-healthcare and clinical decision support// Future generation computer systems-the international journal of escience, Vol.92, 2019, PP. 996-1008, DOI: 10.1016/j.future.2018.07.061.

[25] Gulliford, M.C.; Prevost, A.T.; Charlton, J.; Juszczyk, D.; Soames, J.; McDermott, L.; Sultana, K.; Wright, M.; Fox, R.; Hay, A.D. Effectiveness and safety of electronically delivered prescribing 
feedback and decision support on antibiotic use for respiratory illness in primary care: REDUCE cluster randomised trial// Bmj-british medical journal, Vol.364, №1236, DOI: 10.1136/bmj.1236

[26] Pereboom, M.; Mulder, I.J.; Verweij, S.L.; van der Hoeven, R.T.M.; Becker, M.L. A clinical decision support system to improve adequate dosing of gentamicin and vancomycin// International journal of medical informatics, Vol.124, 2019, PP.1-5, DOI: 10.1016/j.ijmedinf.2019.01.002

[27] Chaturvedi, S.; Kelly, A.G.; Prabhakaran, S.; Saposnik, G.; Lee, L.; Malik, A.; Boerman, C.; Serlin, G.; Mantero, A.M. Electronic Decision support for Improvement of Contemporary Therapy for Stroke Prevention// Journal of stroke \& cerebrovascular diseases, vol.28, issue 3, 2019, PP. 569-573, DOI: 10.1016/j.jstrokecerebrovasdis.2018.10.041.

[28] Arancibia, J.C.N.; Sanchez, F.J.M.; Mejias, A.L.D.; del Castillo, J.G.; Vilaplana, J.C.; Brinon, M.A.G.; Suarez-Cadenas, M.M.; Martinez,

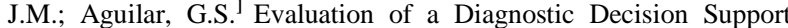
System for the Triage of Patients in a Hospital Emergency Department// International journal of interactive multimedia and artificial intelligence, vol.5, issue 4, 2019, PP.60-67, DOI: 10.9781/ijimai.2018.04.006

[29] Perez-Gonzalez, C.J.; Colebrook, M.; Roda-Garcia, J.L.; RosaRemedios, C.B.Developing a data analytics platform to support decision making in emergency and security management// Expert systems with applications, vol.120, 2019, PP. 167-184, DOI: 10.1016/j.eswa.2018.11.023.

[30] Goehler, A.; Moore, C; Manne-Goehler, J.M.; Arango, J.; D’Amato, L.; Forman, H.P.; Weinerb, J. Clinical DecisionSupport for Ordering CTA-PE Studies in the Emergency Department-A Pilot on Feasibility and Clinical Impact in a Tertiary Medical Center.//Academic radiology, Vol.26, Issue 8, PP.1077-1083, DOI: 0.1016/j.acra.2018.09.009

[31] Breen, C.; Bond, R.; Finlay, D. A clinical decision support tool to assist with the interpretation of the 12-lead electrocardiogram// Health informatics journal, Vol.25, Issue 1, 2019, PP. 51-61, DOI: $10.1177 / 1460458216683534$

[32] Habib, C.; Makhoul, A; Darazi, R. Couturier, R. Health risk assessment and decision-making for patient monitoring and decisionsupport using Wireless Body Sensor Networks// Information fusion, vol.47, 2019, PP.10-22, DOI: 10.1016/j.inffus.2018.06.008.

[33] Hansson, S.O.; Hadorn, G.H. Argument-based decision support for risk analysis// Journal of risk research, Vol.21, Issue 12, 2018, PP 1449-1464, DOI: 10.1080/13669877.2017.1313767.

[34] Gao, W.; Bao, W.P.; Zhou, X. Analysis of cough detection index based on decision tree and support vector machine// Journal of combinatorial optimization, vol.37, issue 1, 2019, PP. 375-384, DOI: 10.1007/s10878-017-0236-8

[35] Muller, T.; Lio, P.Personalisable Clinical DecisionSupport System// ERCIM NEWS, Issue 116, 2019, PP.16-20.

[36] Mork, P.J.; Bach, K. (SelfBACK Consortium) Metadata Correction: A DecisionSupport System to Enhance Self-Management of Low Back Pain: Protocol for the selfBACK Project// JMIR RESEARCH PROTOCOLS, vol 8, e12180, 2019, DOI: 10.2196/12180.

[37] L.Ya.Bukharbaeva, L.M.Bakusov, R.V.Nasyrov, An Automatic Decision-Making System Based on Mathematical Models of Simulation Dynamics Designed for Public Health Management// January 2001, Biomedical Engineering 35(2): pp.100-102, DOI: 10.1023/A:1017653106444

[38] L.Ya.Bukharbaeva, R.V.Nasyrov, I.S.Tiunov, Classification and Structure of Systems of Computer-Aided Design for Biomedical Engineering// Biomedical Engineering, 2015, №9, 49(3), DOI: 10.1007/s10527-015-9526-6

[39] R.A.Badamshin, L.M.Bakusov, R.V.Nasyrov, T.B.Minasov, A method for diagnosis of biomechanical characteristics of the spinal column// Meditsinskaia tekhnika, 2007, №5, 41(3): pp.3-8, DOI: 10.1007/s10527-007-0021-6

[40] Shidlovskij V. A. Sistemnyj analiz vegetativnyh funkcij//Voprosy kibernetiki. 1977. Vyp. 36. S. 5-21. (Shidlovsky V. A. System analysis of autonomic functions//Questions of Cybernetics. 1977. Issue. 36. Pp. 5-21.)

[41] Kotarbin'skij T. Traktat o horoshej rabote.- M.:1975. (Kotarbinsky T. Treatise on good work.- M.:1975.)

[42] Karpman V.L. Testirovanie v sportivnoj medicine/ V.L.Karpman, 3.B.Belocerkovskij, I.A.Gudkov/ M.: «Fizkul'tura i Sport», 1988g. 208 str. (Testing in sports medicine/ V. L. Karpman, 3.B. Belotserkovsky, I. A. Gudkov/ M.: "physical Culture and Sport", 1988 - 208 p.)

[43] Matthew Herland, Taghi M Khoshgoftaar, Randall Wald A review of data mining using big data in health informatics/ Journal of Big Data, 2014,1:2, https://doi.org/10.1186/2196-1115-1-2

[44] Kim, M.; Paini, D.; Jurdak, R. Modeling stochastic processes in disease spread across a heterogeneous social system// Proceedings of the national academy of sciences of the united states of america, Vol.116, Issue 2, PP. 401-406, DOI: 10.1073/pnas.1801429116.

[45] Bartolomeo, N (Bartolomeo, Nicola) ${ }^{[1}$ ] ; Trerotoli, P (Trerotoli, Paolo) ${ }^{[1]}$; Moretti, A (Moretti, Annamaria) ${ }^{[2]}$; Serio, G.A markov model to evaluate hospital readmission// Bmc medical research methodology, Vol. 8, №23, DOI: 10.1186/1471-2288-8-23

[46] Hoogendoorn, M.; Rutten-van Molken, MPMH; Al, MJ; Feenstra, T.L. Developing and Applying a Stochastic Dynamic Population Model for Chronic Obstructive Pulmonary Disease// Value in health, vol.14, issue 8, PP.1039-1047, DOI: 10.1016/j.jval.2011.06.008.

[47] Shams,I. Ajorlou, S. Yang, K. A predictive analytics approach to reducing 30-day avoidable readmissions among patients with heart failure, acute myocardial infarction, pneumonia, or COPD// Health care management science, vol.18, issue1, PP. 19-34, DOI: 10.1007/s10729-014-9278-y.

[48] Soriano, J.B.; Hahsler, M.; Soriano, C; Martinez, C.; de-Torres, J.P.; Marin, J.M.; de Lucas, P.; Cosio, B.G.; Fuster, A.; Casanova, C. Temporal transitions in COPD severity stages within the GOLD 2017 classification system// Respiratory medicine, vol.142, PP. 81-85, DOI: 10.1016/j.rmed.2018.07.019.

[49] L. Ya. Bukharbaeva, $\quad$ L. M. Bakusov, R. V. Nasyrov, F. F. Mannanova, A. V. Goncharov Algorithmic Support for Estimation of the Cost of Services during Dental Treatment//Biomedical engineering, Vol. 35, No. 3, 2001, pp. 171174.

[50] Nasyrov R.V. Mekhanizmy prinyatiya resheniya na osnove dialogovyh modelej navigacii i svertki v problemnom prostranstve// Pedagogicheskij zhurnal Bashkortostana . 2018. № 5 (78). S. 95-101. (Nasyrov R.V. Decision-making mechanisms based on interactive models of navigation and convolution in the problem space// Pedagogical journal of Bashkortostan . 2018. № 5 (78). Pp. 95-101.)

[51] Kruzhkov A.S., Nasyrov R.V., Mullayanov R.R. Analysis of the Correctness of the Model of Biomedical Experiment Based on the Transition Graph by Means of a Matrix Algebra// Information Technology Intelligent Decision Support (ITIDS'2019), Ufa, USATU, (in print)

[52] Zulkarneev R.H., ZagidullinSh.Z., Bakirova V.E., AraslanovaM.S.Decreased fractal dimension of heart rate dynamics in patients with COPD. European Respiratory Journal.- 2006.- Vol.28, Suppl.50.-P.532.

[53] Zulkarneev R.H., ZagidullinSh.Z., Bakirova V.E., AraslanovaM.S.Entropy of breathing rate in patients with severe lung diseases. European Respiratory Journal.- 2006.- Vol.28, Suppl.50.P.204. 